\title{
Optimization of Sono-Electrocoagulation Process for the Removal of Dye Using Central Composite Design
}

\author{
ABDUL RAUF SHAH*, AND HAJIRA TAHIR* \\ RECEIVED ON 03.11.2017 ACCEPTED ON 25.05.2018
}

\begin{abstract}
Sono-electrocaogulation process was successfully applied for the removal of RR120 (Reactive Red 120) in the presence of activated carbon. For this purpose, the process variables were optimized using CCD (Central Composite Design). The operational parameters of the technology were the amount of activated charcoal (0.2-2.0g), amount of $\mathrm{NaCl}$ electrolyte (1-10g), sonication time (30-120 min) and RR120 dye concentration (40-120 mg/L), respectively. Consequently, the $100 \%$ dye removal was determined at the optimal conditions for the process obtained by CCD. In addition, the sonication time, amount of adsorbent and dye concentrations were found the significant process factors. Furthermore, the effects of other parameters like the electric current, current efficiency, amount of $\mathrm{NaCl}$, temperature and formation of coagulants were also studied in the dye removal process, separately. The FTIR (Fourier Transfer Infrared) spectrums were monitored to identify the classes of functional groups present in the dye molecule before and after the treatment. Therefore, the sono-electrocaogulation process was proved an effective technique for purifying simulated wastewater containing RR120 dye.
\end{abstract}

Key Words: Sono-Electrocoagulation, Reactive Red120, Central Composite Design, Activated Carbon, Fourier Transfer Infrared.

\section{INTRODUCTION}

$\mathrm{W}$

ater is essential for the existence of life on the earth. It provides medium to all biochemical activities in the living organisms. It is used for domestic, agriculture and industries. Moreover, it has the large consumption in industries. A large volume of wastewater is discharged off from industries. Due to improper treatment of wastewaters, contaminants are being added in water natural resources. Therefore, water pollution has become a major problem in the world. In the past, different methods have been adopted to treat wastewater to reduce water pollution. Different treatment methods include chemical coagulation, adsorption, chemical-oxidation, photolysis, photo-catalysis, electro-photocatalysis [1-2]. Among different treatment processes, the EC (Electrocoagulation) process has also been used to treat wastewater. Furthermore, It has been applied to remove oils, colorants, metals, halides, etc. [3-4]. In the recent years, the EC process has been studied by researchers for the treatment of simulated and real wastewater of colors [5- 
6]. The EC process requires proper conductivity of the system and less energy consumption [7]. The process has been proved to be a precised, critical and less timeconsuming technique [8-9]. Now-a-days, the applications of ultrasonic process are gaining importance by many researchers for the treatment of raw water [10-11]. The ultrasonic waves generated with ultrasonicator are transmitted in the liquid medium. As a result, air cavities are formed: cause molecular disintegrations. Additionally, they also generate ions and radicals in the solution [1213]. Indeed, the sonic field increases the rate of formation of coagulants, during the EC method [14-15]. By employing the ultrasonic waves with the $\mathrm{EC}$ process, the $\mathrm{OH}^{\cdot}$ radicals are generated in wastewater which favor the subsequent oxidation of pollutants. Furthermore, many researchers have studied that the generation of hydroxyl radicals follow the first order kinetics [16]. Moreover, oxygen evolution occurs at the aluminium anode [17-18]. The mechanism of water sonolysis is represented as follows:

$\begin{array}{lll}\left.\left.\mathrm{H}_{2} \mathrm{O}+1\right)\right) & \rightarrow & \mathrm{H}^{\bullet}+\mathrm{OH}^{\bullet} \\ \mathrm{H}^{\bullet}+\mathrm{O}_{2} & \rightarrow & \mathrm{HOO}^{\bullet} \\ \text { Dye }+\mathrm{OH}^{\bullet} & \rightarrow & \text { Side products } \\ \text { Dye }+\mathrm{HOO}^{\bullet} & \rightarrow & \text { Side products }\end{array}$

Water molecules undergo decomposition reaction in the presence of sonic field. It was firstly identified by Weiss, while, the synthesis of hydrogen peroxide was analyzed by Fitzgerald [19]. The generation of hydrogen peroxide, additionally, helps the EC process in contaminants removal from wastewater [20].

Pollutants $+\mathrm{H}_{2} \mathrm{O}_{2} \rightarrow$ side products

The diffusion-controlled processes are involved for the interactions of electrons containing water molecules, hydrogen atoms and $\mathrm{OH}^{*}$ radicals. However, the chemical species like hydrated electrons and hydrogen atoms have less reaction probability with the dye molecules. Because, oxygen molecule acts as scavenger of hydrogen radicals and hydrated electrons. Consequently, these species are transformed into peroxide and superoxide radicals. Because, the reduction potential of RR120 dye azo group is more negative about $-0.35 \mathrm{~V}$ (versus NHE) as compared to the reduction potentials of perhydroxyl $(-0.33 \mathrm{~V})$ and superoxide $(-0.037 \mathrm{~V})$ radicals . Therefore, perhydroxyl and superoxide radicals jointly couldn't reduce the azo group of RR120 at pH 7. Because, azo group is strong reducing agent. Hence, it does not undergo reduction process. Furthermore, Reactive dyes are consumed at large industrial scale [21]. So, the removal of an anionic dye (RR120) has been studied. It has the potential risk to the bio-ecosystem because of its poor biodegradability [2223]. Additionally, optimization of experimental variables on EC was analyzed by RSM (Response Surface Methodology) [24]. The purpose of RSM is to perform fewer experiment runs to optimize the operational parameters. Factors such as the amount of adsorbent (activated carbon) (g), electrolyte dosage of $\mathrm{NaCl}(\mathrm{g})$, sonication time $(\mathrm{min})$ and dye concentration $(\mathrm{mg} / \mathrm{L})$ were selected as the operational parameters. Whereas, the removal of dye from simulated wastewater was analyzed as a response [25].

\section{MATERIALS AND METHOD}

\subsection{Experiment Section}

\subsubsection{Apparatus and Instruments}

The sono-electrocoagulation process was performed at laboratory scale. Lab setup is shown in Fig. 1. The experimental runs of the sono-electrocoagulation were performed in a $1000 \mathrm{~mL}$ cylindrical glass reactor and placed in water bath sonicator [Elmasonic E $30 \mathrm{H}$ ]. Aluminium and graphite electrodes were selected as the anode and cathode and they were in rod shape. All the experiments 
were attempted at $34^{\circ} \mathrm{C}$. The weight of substances was measured by the Adventure Oahu's digital weighing balance model AR2140. While, the $\mathrm{pH}$ and temperature of dye solutions were measured with a Portable $\mathrm{pH} / \mathrm{EC} / \mathrm{TDS}$ / Temperature HANNA, H19811-5. The absorbance was measured with UV/VIS Spectrophotometer T80 (PG Instruments LTD). Whereas, FTIR model NICOLET 67000 was used to obtain spectrums of pure RR120 dye and its sludge formed by the EC treatment.

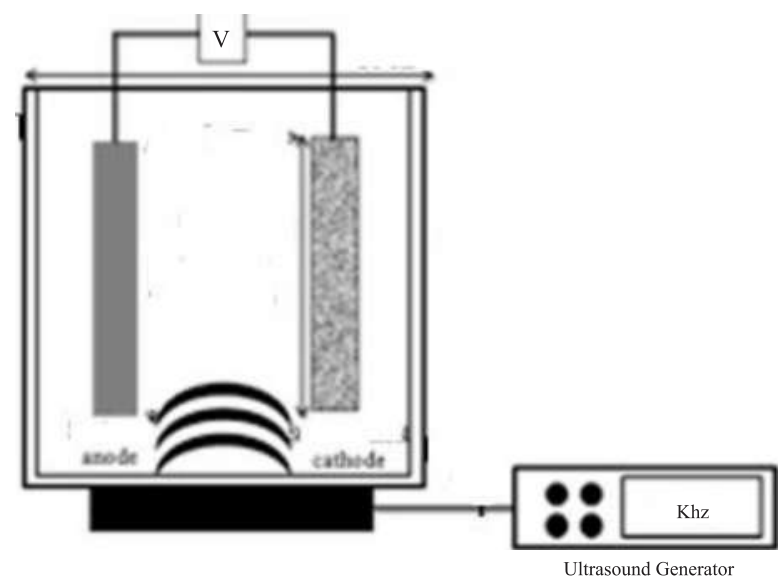

FIG. 1. THE SONO-ELECTROCOAGULATION SETUP FOR RR120 DYE REMOVAL

\subsubsection{Reagents and Material}

The physiochemical properties of RR120 are shown in Table 1.

\subsubsection{Experimental Procedure}

A stock solution of artificial RR120 dye was prepared. The diluted solutions were prepared between 30-1200mg/ $\mathrm{L}$ from the stock solution. The number of experimental runs were determined by the Minitab 17 software. At the beginning of each trial, a fresh solution of RR120 dye, activated carbon(s) and $\mathrm{NaCl}(\mathrm{s})$ according to the experimental runs of the EC process was transferred into a $1000 \mathrm{~mL}$ glass reactor. After that, the EC reactor was turned on in water bath Sonicator (Elmasonic E 30H) for desired ultrasonic intervals as designed by the Minitab 17 software. The sono-electrocoagulation reactor was connected to a digital DC power supply (Yaxun 1502DD; $15 \mathrm{~V}, 2 \mathrm{~A})$. The amplitude was set at $100 \%$. After the specified interval of the sono-electrocoagulation process the samples were ejected and after filtration they were

TABLE 1. PROPERTIES OF REACTIVE RED 120 DYE

\begin{tabular}{|c|c|}
\hline Dye & Reactive Red 120 \\
\hline Chemical Structure & \\
\hline CAS No. & $61951-82-4$ \\
\hline Chemical Name & Reactive Red 120 \\
\hline Synonyms: & Reactive Red HE7B \\
\hline Molecular Formula & $\mathrm{C} 44 \mathrm{H} 24 \mathrm{C} 12 \mathrm{~N} 14 \mathrm{O} 20 \mathrm{~S} 6 \mathrm{Na} 6$ \\
\hline Formula Weight & 1469.98 \\
\hline Properties and Applications & $\begin{array}{l}\text { It is soluble in water. It is used for colorful blue-ray red color, iron particles change this color into slightly yellow and } \\
\text { copper ions successively in turn light blue. Furthermore, primarily it is used for cotton or viscose fiber volume dyes } \\
\text { and disseminated. It conjointly appropriate for direct printing and also suitable for polyester/cotton, polyester/stick } \\
\text { blended coloring. }\end{array}$ \\
\hline $\max$ & $532 \mathrm{~nm}$ \\
\hline CB Number & $\mathrm{CB} 0402020$ \\
\hline
\end{tabular}

Mehran University Research Journal of Engineering \& Technology, Volume 38, No. 2, April, 2019 [p-ISSN: 0254-7821, e-ISSN: 2413-7219] 
analyzed at $\lambda_{\max }$ of $532 \mathrm{~nm}$ with T80 UV-VIS Spectrophotometer. Furthermore, the electrodes were cleaned with $5 \% \mathrm{H}_{2} \mathrm{SO}_{4}(\mathrm{w} / \mathrm{v})$ solutions and the $\mathrm{EC}$ reactor was also washed by utilizing $2 \% \mathrm{HCl}$ solutions.

\subsection{Response Surface Methodology}

\subsubsection{Central Composite Design}

The amount of adsorbent (Activated Carbon), electrolyte quantity $(\mathrm{NaCl})$, sonication time and dye concentrations (RR120) were optimized for the removal of dye using CCD. The \% removal of dye was considered to be dependent on the amount of adsorbent (Activated Carbon), the electrolyte quantity $(\mathrm{NaCl})$, sonication time and dye concentration (RR120).

$$
y=\beta_{o}+\sum_{i=1}^{4} \beta_{1} x_{1}+\sum_{i=1}^{4} \sum_{j=1}^{4} \beta_{i j} x_{1} x_{j}+\sum_{i=1}^{4} \beta_{11} x_{1}^{2}
$$

The symbols $X_{i} X_{j}$ are showing the independent variables, $\beta_{0}$ is the intercept of the model. The linear coefficient is $\beta_{\mathrm{i}}$, and the quadratic coefficients are $\beta_{\mathrm{ii}}, \beta_{\mathrm{ij}}$.

\subsubsection{Statistics Modeling}

The Minitab 17 Software was used to design the experimental runs. It was also employed for calculating ANOVA (Analysis of Variance), multiple regression analysis, full interaction plots and the main interaction effects. Furthermore, the Sigma Plot 12 software was used to draw the response surface plots in order to study the effects of two variables at a time on the response.

\section{RESULTS AND DISCUSSION}

\subsection{Mechanism of the EC Process}

The mechanisms of the EC process are not so simple. It needs further study to illustrate the EC mechanisms for the removal of pollutants from wastewater [26]. The mechanism of the process is represented as follows:

Mechanism

At Anode:

$\mathrm{Al} \quad \rightarrow \quad \mathrm{Al}^{+3}+3 \mathrm{e}^{\prime}$

Bulk of solution:

$2 \mathrm{Al}^{+3}+6 \mathrm{H}_{2} \mathrm{O} \quad \rightarrow \quad 2 \mathrm{Al}(\mathrm{OH})_{3}+6 \mathrm{H}^{+}$

At Cathode :

$6 \mathrm{H}^{+}{ }_{(\mathrm{aq})}+6 \mathrm{e}^{-} \quad \rightarrow \quad 3 \mathrm{H}_{2(\mathrm{~g})}$

Over all reaction:

$\mathrm{Al}(\mathrm{OH})_{3}+$ pollutant $\left(\mathrm{C}_{44} \mathrm{H}_{24} \mathrm{Cl}_{2} \mathrm{~N}_{14} \mathrm{O}_{20} \mathrm{~S}_{6} \mathrm{Na}_{6}\right) \rightarrow$ coagulantdye (in solution)

The removal potency of the dye depends on the amount of $\mathrm{Al}(\mathrm{OH})_{3}$ generated by the oxidation of the metal electrode. Consequently, the high removal efficiency was observed for the longer time period and the maximum electric potentials. The $\mathrm{pH}$ of the system also favors the synchronous formation of $\mathrm{Al}(\mathrm{OH})_{3}$. While, $\mathrm{Al}^{3+}$ and $\mathrm{OH}^{-}$ions are generated by the electrode reactions as shown in Equation (7-9). After that, they form various aluminium species such as $\mathrm{Al}(\mathrm{OH})^{2+}$, $\mathrm{Al}(\mathrm{OH})_{2}{ }^{+}, \mathrm{Al}(\mathrm{OH})_{2}{ }^{4+}, \mathrm{Al}(\mathrm{OH})_{4}$ and polymeric species such as $\mathrm{Al}_{6}(\mathrm{OH})^{3+}, \mathrm{Al}_{7}(\mathrm{OH})_{17}{ }^{4+}, \mathrm{Al}(\mathrm{OH})^{4+}, \mathrm{Al}_{8}(\mathrm{OH})_{20}{ }^{4+}$, $\mathrm{Al}_{13} \mathrm{O}_{4}(\mathrm{OH})_{24}{ }^{7+}, \mathrm{Al}_{13}(\mathrm{OH})_{34}{ }^{5+}$, finally, which are transformed into $\mathrm{Al}(\mathrm{OH})_{3}$ chemical species according to the complex precipitation kinetics. Numerous interaction mechanisms are possible between the dye molecules and hydrolysis products and their rates depend on the $\mathrm{pH}$ of the EC system and sorts of particles present in the 
system. The two major interface mechanisms were being considered in the recent years. The precipitation and adsorption processes, being proposed at separate $\mathrm{pH}$ data. Flocculation process occurs in a less acidic media and elucidated as precipitation. While, the adsorption process is followed at high $\mathrm{pH}$. At high basic media $\mathrm{pH}$ $>9, \mathrm{Al}(\mathrm{OH})_{4}-$ ions are additionally present in the system. $\mathrm{Al}(\mathrm{OH})_{3}$ has reactive surface sites naturally which favor fast adsorption of solvent impurities and accumulation of colloidal particles [27]. Furthermore, Al precipitates are generated at high $\mathrm{pH}>7$.

\subsection{FTIR Analysis of RR120 Dye}

Fig. 2(a-b) represent the FTIR spectrum of RR120 dye before and after the sono-electrocoagulation treatment. The characteristic peak which represents the NitrogenHydrogen stretching present outside the benzene ring appeared near to $3500 \mathrm{~cm}^{-1}$. While the peak which is showing the $\mathrm{CH}$ (Carbon-Hydrogen) distortion in $\mathrm{CH}_{3}$ group appeared at $1365 \mathrm{~cm}^{-1}$. The peak at $1174 \mathrm{~cm}^{-1}$ is owing to $\mathrm{CH}$ stretching in benzene ring. The peaks at $3000-3100 \mathrm{~cm}^{-1}$ represent at the stretching of $\mathrm{CH}$ in benzene. Moreover, between 1400-1600 cm-1 represent $\mathrm{C}=\mathrm{C}$ stretching in benzene ring. The low intensity absorption was observed between $4000-2000 \mathrm{~cm}^{-1}$. The number of peaks was additionally reduced of the dye once its surface was attached by the coagulants. The percent transmittance decreased at $3446 \mathrm{~cm}^{-1}$ after the sono-electrocoagulation treatment of RR120 dye simulated effluent. The broader peak at $3446 \mathrm{~cm}^{-1}$ is showing that $-\mathrm{OH}$ groups have been increased in the sludge. Which is further confirmed from its high absorption in the spectrum.

\subsection{The Sono-Electrocoagulation Process for the Removal of RR 120 Dye}

\subsubsection{RSM to Optimize the Operative Parameters}

Optimization of the sono-electrocoagulation process OOP (Optimize Operating Parameters) was carried out. The amount of adsorbent (activated carbon) was varied from $(0.2-2 \mathrm{~g})$, whereas the amount of electrolyte $(\mathrm{NaCl})$ was maintained as $(1.0-10 \mathrm{~g})$. The sonication time at the lowest level of $30 \mathrm{~min}$ to the highest level of $120 \mathrm{~min}$ was retained. The concentration of RR120 dye with the lowest level of $30 \mathrm{mg} / \mathrm{L}$ to the highest level of $120 \mathrm{mg} / \mathrm{L}$ was selected.

The RSM model is represented in Equation (10):

$\%$ Color Removal $=103.7+10.8 \mathrm{~A}+0.83 \mathrm{~B}+0.232 \mathrm{C}-0.659$ D-2.33 AA-0.093 BB-0.00340 CC-0.00024 DD-0.062 $\mathrm{AB}-0.0926 \mathrm{AC}+0.0625 \mathrm{AD}+0.0062 \mathrm{BC}+0.0014 \mathrm{BD}+$ $0.00653 \mathrm{CD}$

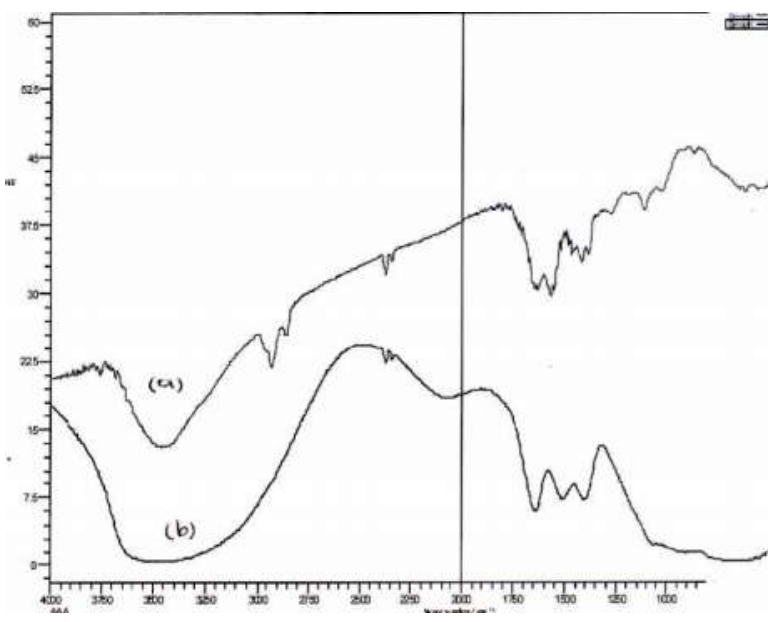

FIG. 2. THE FTIR SPECTRUM OF (a) A PURE RR 120 DYE (b) THE FTIR SPECTRUM OF RR 120 DYE AFTER THE SONO-EC TREATMENT

Mehran University Research Journal of Engineering \& Technology, Volume 38, No. 2, April, 2019 [p-ISSN: 0254-7821, e-ISSN: 2413-7219] 
While A, B, C and D are representing the coded variables such as the amount of adsorbent (Activated carbon), the quantity of electrolyte $(\mathrm{NaCl})$, sonication time and $\mathrm{RR} 120$ dye concentrations, respectively. The optimum parameters were evaluated by the RSM graphs as delineated in Fig. 3(a-c).

The sono-electrocoagulation process is enhanced gradually by increasing the sonication time and amount of electrolyte. The regular residuals for the $\%$ dye removal and frequency are represented in Fig. 4(a).

The Fig. 4(a) is showing that the utmost residuals lie within the intervals between -5 and 5 . A normal probability graph for the RR120 dye removal is shown in Fig. 4(b). It allocates that the points are symmetrically around the central line. The data sets are showing a linear relation and that is confirmed by the experimental design. Additionally, the CCD has the significant importance. It is cleared from Fig. 4(b) that there is no significant outlier relative to a normal distribution is noticed within the plots. By the examination of variance, it is generally more viable (and straightforward) to perform this with the residuals. The residuals and the observation order of the data are shown in Fig. 4(c). The data points are shown on the $x-$ axis. While Experiments No. 4.11, 29 are providing the large residuals. The significance and non-significance of variables can be identified by a Pareto Chart as displayed in Fig. 5.

The effective parameters of the sono-electrocoagulation process for the removal of RR120 dye are the sonication time, dye concentration and amount of adsorbent. Other significant factors include the amount of adsorbent (activated carbon), and combined effects of other respective factors $(\mathrm{CD})$ and $\mathrm{C}^{2}$.

Table 2 represents the model outline of the experimental design found by the Minitab 17 Software for sono-electrocoagulation method for the removal of RR120. The $R^{2}$ value 0.8226 is representing the importance of the model. Whereas, its adjusted value is found to be 0.6673 . When model does not show worth, the lack of fit shows significance. The p-value for the lack of fit is found to be $>0.05$ for RR120 removal: shows that the F-statistic is insignificant, suggesting the consequential model relationship between the elemental factors and process response. The adequacy of the
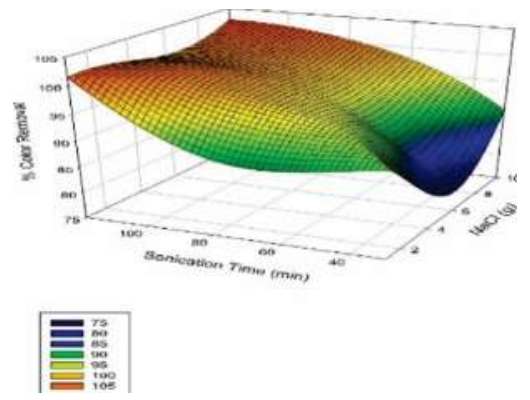

(a) AMOUNT OF ELECTROLYTE (g) AND SONICATION TIME (min)
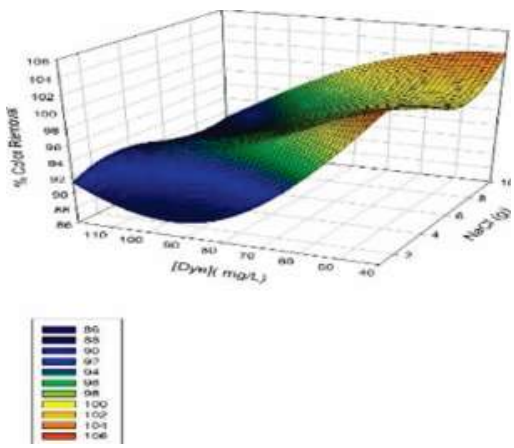

(b) AMOUNT OF ELECTROLYTE (g) AND DYE CONCENTRATION $(\mathrm{mg} / \mathrm{L})$
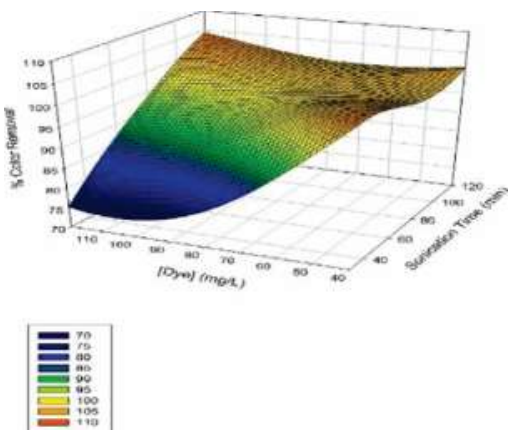

(c) SONICATION TIME (min) AND DYE CONCENTRATION $((\mathrm{mg} / \mathrm{L})$

FIG. 3. RESPONSE SURFACE DIAGRAMS AS A FUNCTION OF \% DYE REMOVAL 
regression model for explaining the experimental data at $95 \%$ confidence level is tested by the ANOVA. It includes some statistic factors such as lack of fit, $\mathrm{R}^{2}$, and adjusted $\mathrm{R}^{2}$. The ANOVA results are shown in Table 3, representing that the model is extremely impertinent, as the $\mathrm{P}$-value for the model is $0.001(\mathrm{P}$-value $<0.05)$. The higher $\mathrm{R}^{2}$ value is indicated that the applied model offers conventional estimated response of the system. The significance of "lack of fit" with (P-value $>0.05)$ is indicated that the factors are satisfactorily fitted the data of target response. All relations within the regression model aren't equally important. The significance of each term is analyzed by the student's ttest and P-values, data is represented in Table 4. The t-

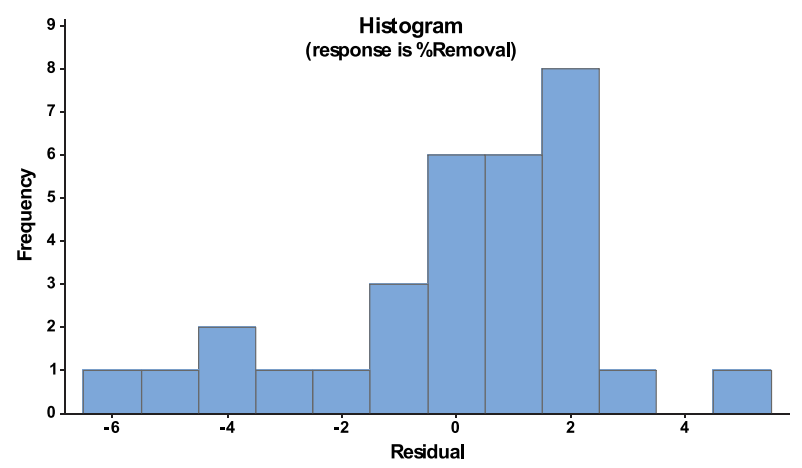

FIG. 4(a). HISTOGRAM OF REGULAR RESIDUAL FOR \% REMOVAL VERSUS FREQUENCY

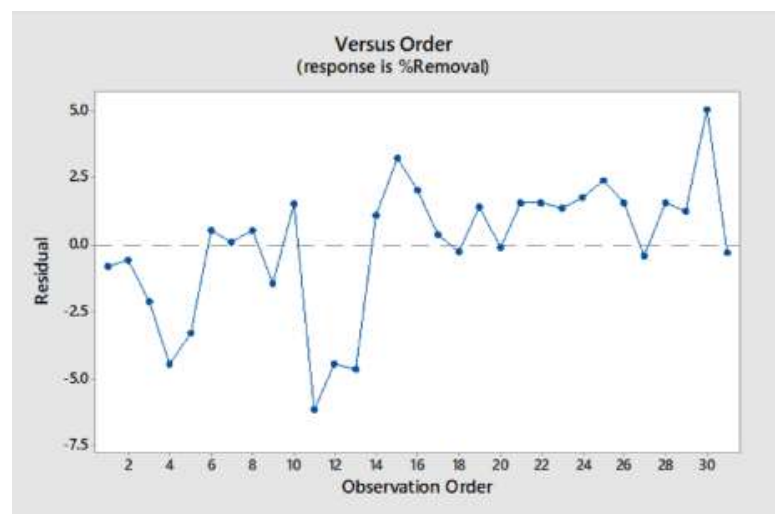

FIG. 4(c). THE COMPARISON BETWEEN OBSERVED ORDER AND REGULAR RESIDUAL test represents the quantitative relation of the estimable parameters and their impacts to the computable parameter of variance. The t-test $(\mathrm{t}-\mathrm{cal}<\mathrm{t}-\mathrm{tab})$ and smaller $\mathrm{P}$-values of the coefficients declare the additional significance. Table 3 represents the analysis of variance ANOVA and P-values. It is cleared from the data that some P-values are reduced compared to the confidence level (0.05). It represents the appropriateness and importance of the processes. The terms B, AB, AC, $\mathrm{AD}, \mathrm{BC}, \mathrm{BD}$ are not found to be comparatively essential for the elimination of the RR120 dye. The factor sonication time (C), dye concentration (D) and amount of adsorbent are the foremost noteworthy dynamic which are agreed by the Pareto chart too.

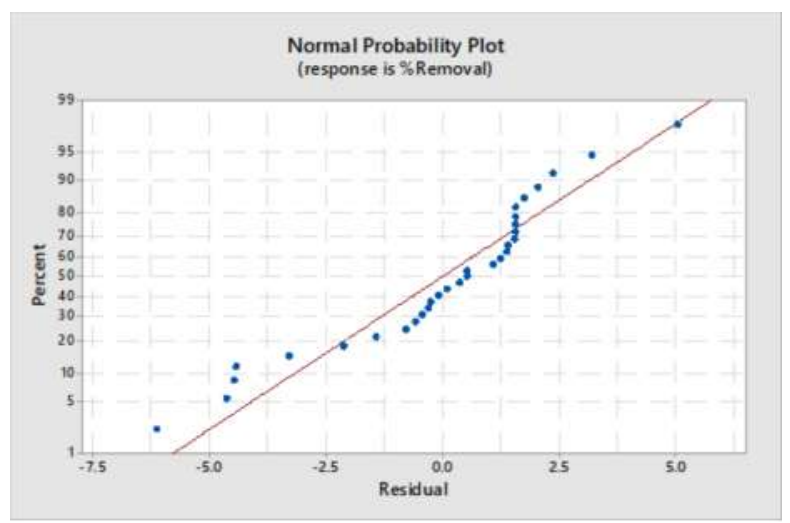

FIG. 4(b). NORMAL PROBABILITY PLOT FOR REGULAR RESIDUAL

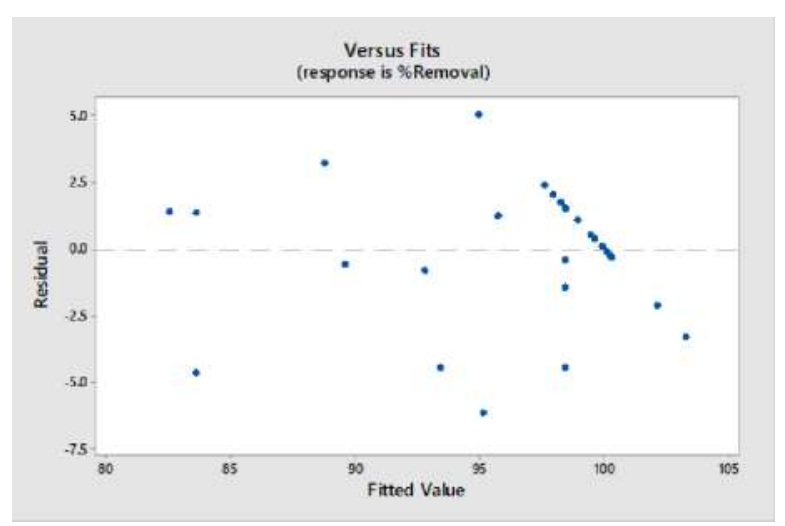

FIG. 4(d). THE RESIDUAL PLOT AGAINST FITTED VALUES

Mehran University Research Journal of Engineering \& Technology, Volume 38, No. 2, April, 2019 [p-ISSN: 0254-7821, e-ISSN: 2413-7219] 


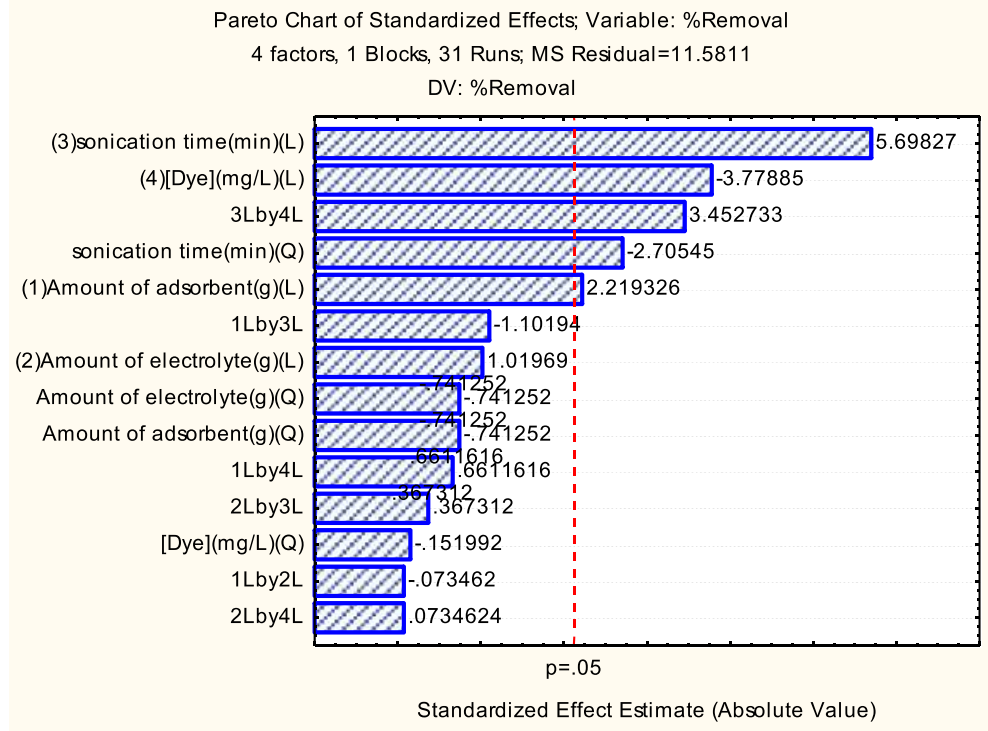

FIG. 5. PARETO CHART OF COEFFICIENTS FOR THE SONO-EC SYSTEM

TABLE 2. MODEL SUMMARY OF EXPERIMENTAL DESIGN OF SONO-EC PROCESS FOR THE REMOVAL OF RR120

\begin{tabular}{|c|c|}
\hline $\mathrm{S}$ (Root Mean Square Error) & 3.403 \\
\hline $\mathrm{R}^{2}$ (Correlation Coefficient) & $82.26 \%$ \\
\hline $\mathrm{R}^{2}(\mathrm{adj})$ & $66.73 \%$ \\
\hline $\mathrm{R}^{2}(\mathrm{pred})$ & $11.16 \%$ \\
\hline
\end{tabular}

TABLE 3. STATISTICAL ANALYSIS OF VARIANCE FOR THE SONO-EC PROCESS

\begin{tabular}{|c|c|c|c|c|c|}
\hline Source & DF & Adj SS & Adj MS & F-Value & P-Value \\
\hline Model & 14 & 859.1 & 61.36 & 5.30 & 0.001 \\
\hline Linear & 4 & 610.5 & 152.6 & 13.18 & 0.000 \\
\hline A & 1 & 57.04 & 57.04 & 4.93 & 0.041 \\
\hline B & 1 & 12.04 & 12.04 & 1.04 & 0.323 \\
\hline C & 1 & 376.0 & 376.0 & 32.47 & 0.000 \\
\hline D & 1 & 165.3 & 165.4 & 14.28 & 0.002 \\
\hline Square & 4 & 89.71 & 22.42 & 1.94 & 0.153 \\
\hline A*A & 1 & 6.36 & 6.363 & 0.55 & 0.469 \\
\hline B*B & 1 & 6.36 & 6.363 & 0.55 & 0.469 \\
\hline C*C & 1 & 84.77 & 84.76 & 7.32 & 0.016 \\
\hline D*D & 1 & 0.27 & 0.268 & 0.02 & 0.881 \\
\hline 2-Way Interaction & 6 & 158.8 & 26.47 & 2.29 & 0.087 \\
\hline A*B & 1 & 0.06 & 0.062 & 0.01 & 0.942 \\
\hline A*C & 1 & 14.06 & 14.06 & 1.21 & 0.287 \\
\hline A*D & 1 & 5.06 & 5.062 & 0.44 & 0.518 \\
\hline B*C & 1 & 1.56 & 1.562 & 0.13 & 0.718 \\
\hline B*D & 1 & 0.06 & 0.062 & 0.01 & 0.942 \\
\hline C*D & 1 & 138.0 & 138.0 & 11.92 & 0.003 \\
\hline Error & 16 & 185.3 & 11.58 & & 2.91 \\
\hline Lack-of-Fit & 10 & 153.5 & 15.35 & & 0.102 \\
\hline Pure Error & 6 & 31.71 & 5.286 & & \\
\hline Total & 30 & 1044 & & & \\
\hline
\end{tabular}

Mehran University Research Journal of Engineering \& Technology, Volume 38, No. 2, April, 2019 [p-ISSN: 0254-7821, e-ISSN: 2413-7219] 


\subsubsection{Main Interaction Plots}

The simplest graphical tool (Main Effects Plot) is to see, whether the analysis pattern is statistically vital or not. In this plot the response means are plotted against levels of operational parameters. There is no main effect: When factors levels response overlap $\mathrm{x}$-axis (response mean).
In plot Fig. 6 is showing that factors levels significantly moving the target mean values.

\subsubsection{Full Interaction Plots}

The full interaction plot shows response means for the levels of one factor on the $\mathrm{x}$-axis and a separate line for

TABLE 4. THE ESTIMATED PARAMETER AND THEIR IMPLICIT CODED UNITS

\begin{tabular}{|c|c|c|c|c|c|c|}
\hline Term & Effect & Coef & SE Coef & T-Value & P-Value & VIF \\
\hline Constant & & 98.43 & 1.29 & 76.52 & 0.000 & \\
\hline A & 3.083 & 1.542 & 0.695 & 2.22 & 0.041 & 1.00 \\
\hline B & 1.417 & 0.708 & 0.695 & 1.02 & 0.323 & 1.00 \\
\hline $\mathrm{C}$ & 7.917 & 3.958 & 0.695 & 5.70 & 0.000 & 1.00 \\
\hline $\mathrm{D}$ & -5.250 & -2.625 & 0.695 & -3.78 & 0.002 & 1.00 \\
\hline $\mathrm{A}^{*} \mathrm{~A}$ & -0.943 & -0.472 & 0.636 & -0.74 & 0.469 & 1.03 \\
\hline$B * B$ & -0.943 & -0.472 & 0.636 & -0.74 & 0.469 & 1.03 \\
\hline$C * \mathrm{C}$ & -3.443 & -1.722 & 0.636 & -2.71 & 0.016 & 1.03 \\
\hline $\mathrm{D} * \mathrm{D}$ & -0.193 & -0.097 & 0.636 & -0.15 & 0.881 & 1.03 \\
\hline$A * B$ & -0.125 & -0.062 & 0.851 & -0.07 & 0.942 & 1.00 \\
\hline $\mathrm{A}^{*} \mathrm{C}$ & -1.875 & -0.938 & 0.851 & -1.10 & 0.287 & 1.00 \\
\hline$A^{*} \mathrm{D}$ & 1.125 & 0.562 & 0.851 & 0.66 & 0.518 & 1.00 \\
\hline $\mathrm{B}^{*} \mathrm{C}$ & 0.625 & 0.312 & 0.851 & 0.37 & 0.718 & 1.00 \\
\hline$B * D$ & 0.125 & 0.062 & 0.851 & 0.07 & 0.942 & 1.00 \\
\hline$C * D$ & 5.875 & 2.937 & 0.851 & 3.45 & 0.003 & 1.00 \\
\hline
\end{tabular}

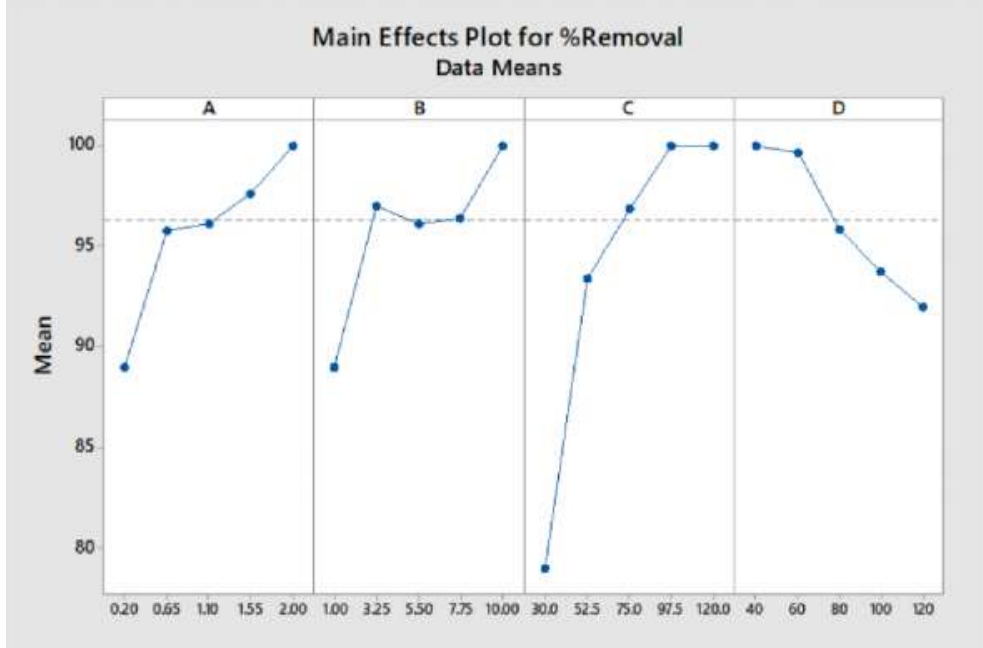

FIG. 6. MAIN EFFECTS PLOT FOR \% REMOVAL OF RR120 
each level of another factor. If Parallel lines are observed: means that no variation in target response due to amendment in factors levels. If response slope is higher: means additional robust interactions are present among levels of factors for the target response. This plot is reciprocal to ANOVA test. Interaction plot is very useful if there are significant interactions are present among factors for the response values. The lines are not parallel in Fig. 7 for \% color removal.

\subsubsection{Effect of Activated Carbon on Sono-ECProcess}

Activated carbon has been used to study its effect on the dye removal with sono-electrocoagulation process. Because, it is an excellent adsorbent [28]. Furthermore, on the surface of activated carbon, contaminants are adsorbed. It also reduces toxic nature of $\mathrm{Cl}_{2} / \mathrm{HOCl} / \mathrm{OCl}^{-}$ into non-toxic $\mathrm{Cl}^{-}$ions [29]. The Fig. 8(a-b) represent the efficacy of sono-electrocoagulation process regarding the amount of (AC) adsorbent. It is determined by the Response surface graphs (A) that the amount of adsorbent directly proportional to the dye removal potency. From the given Fig. 8(b) represents that mutually the amount of adsorbent and electrolyte considerably affect on the percent removal of the dye. Sonication time and amount of adsorbent also enhanced the percent removal of RR120 dye.

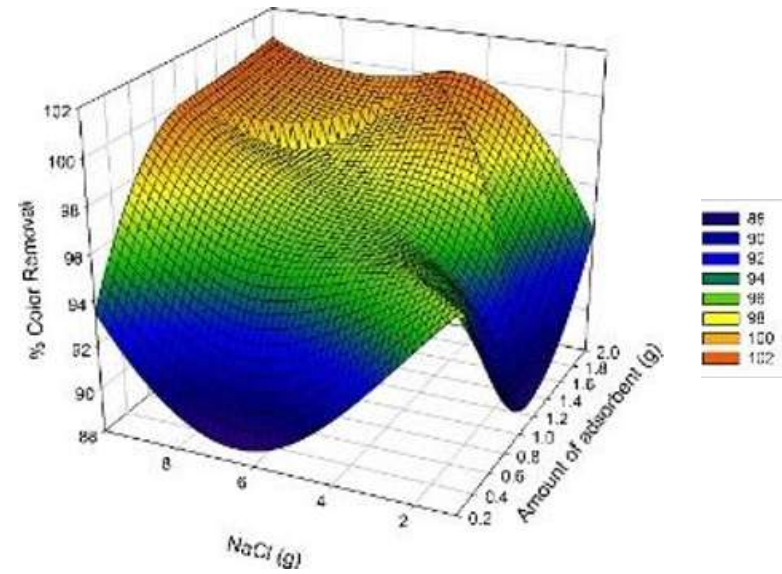

FIG. 8(a). AMOUNT OF ADSORBENT (g) AND AMOUNT OF ELECTROLYTE (g)

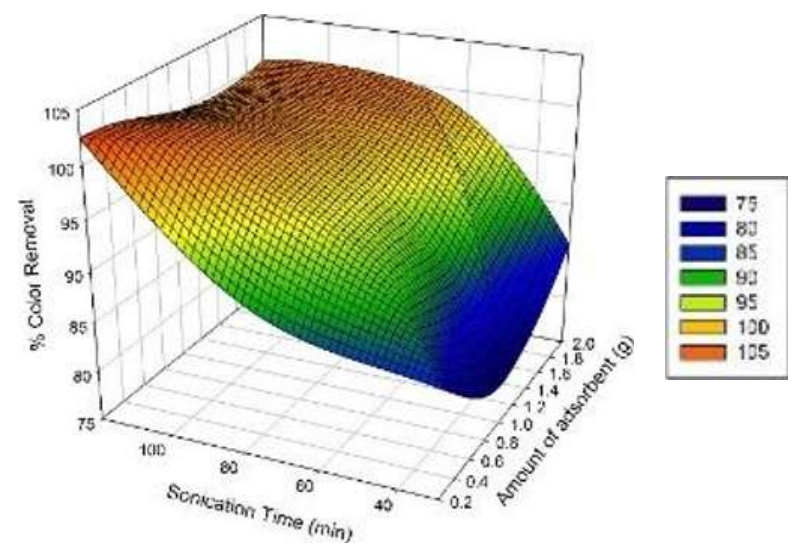

FIG. 8(b). AMOUNT OF ADSORBENT (g) AND SONICATION TIME ( $\mathrm{min})$

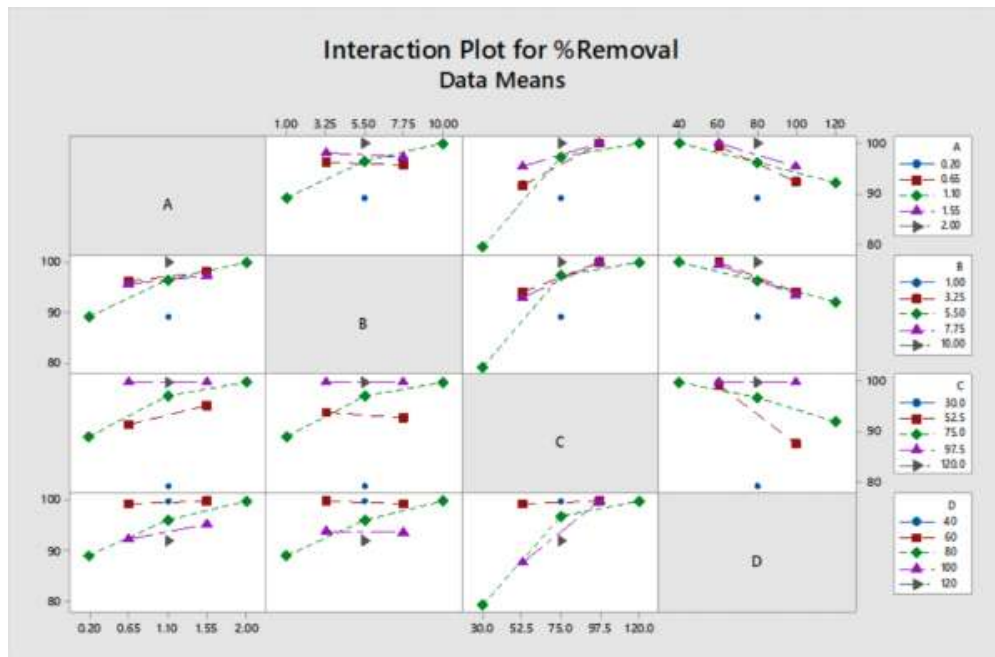

FIG. 7. FULL INTERACTION PLOTS FOR RR120 DYE REMOVAL BY SONO-EC PROCESS

Mehran University Research Journal of Engineering \& Technology, Volume 38, No. 2, April, 2019 [p-ISSN: 0254-7821, e-ISSN: 2413-7219] 


\section{EFFECTS OF DIFFERENT OPERATIONAL PARAMETERS ON SONO-EC PROCESS FOR RR120 REMOVAL}

\subsection{Evaluation of Current Efficiency and Energy Cost}

The current efficiency was observed to be (108-154\%), with artificial RR120 dye system. This distinction in mass was processed by the corrosion pitting on the surface of aluminium electrode. This mass was mistakenly patterned because of metal surface disintegrated by the following electro-chemical processes.

$2 \mathrm{Al}+6 \mathrm{HCl} \quad \rightarrow \quad 2 \mathrm{AlCl}_{3}+3 \mathrm{H}_{2}$

$\mathrm{AlCl}_{3}+3 \mathrm{H}_{2} \mathrm{O} \quad \rightarrow \quad \mathrm{Al}(\mathrm{OH})_{3}+3 \mathrm{HCl}$

In aluminum, the observed results are considerably over the expected values for $100 \%$ effectiveness process agreed by Faraday's law. This super-faradaic efficiency is due to the aluminum dissolution process, which is compared to the oxidation of the aluminum surface with the synchronous decrease of water to breed hydrogen gas, according to Equation (13) [30]:

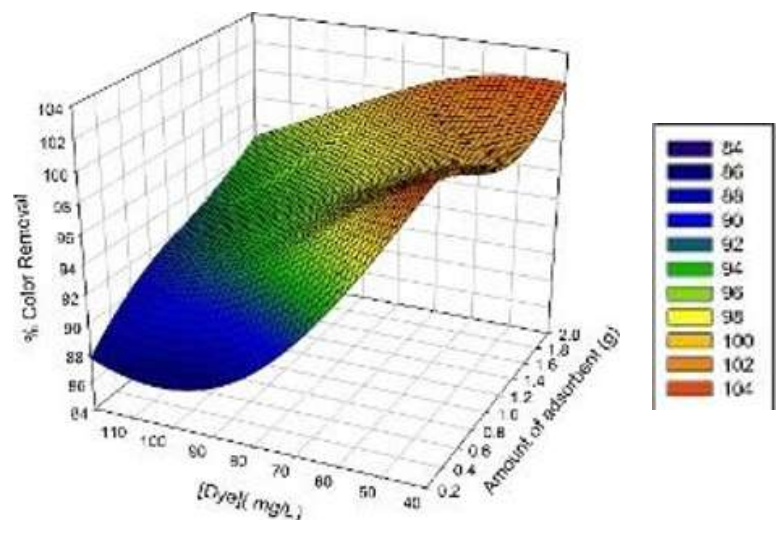

FIG. 8(c). AMOUNT OF ADSORBENT(g) AND DYE CONCENTRATION $(\mathrm{mg} / \mathrm{L})$

$\begin{array}{lll}2 \mathrm{Al}+6 \mathrm{H}_{2} \mathrm{O} & \rightarrow & 2 \mathrm{Al}^{+3}+3 \mathrm{H}_{2}+6 \mathrm{OH}^{-} \\ \mathrm{Al}^{+3}+3 \mathrm{H}_{2} \mathrm{O} & \rightarrow & \mathrm{Al}(\mathrm{OH})_{3}+3 \mathrm{H}^{+} \\ 2 \mathrm{H}_{2} \mathrm{O} & \rightarrow & \mathrm{O}_{2}+4 \mathrm{H}^{+}+4 \mathrm{e}^{-} \\ 2 \mathrm{Cl}^{-} & \rightarrow & \mathrm{Cl}_{2}+2 \mathrm{e}^{-} \\ \mathrm{Cl}_{2}+\mathrm{H}_{2} \mathrm{O} & \rightarrow & \mathrm{HOCl}^{+} \mathrm{H}^{+}+\mathrm{Cl}^{-} \\ \mathrm{HOCl} & \leftrightarrow & \mathrm{OCl}^{-}+\mathrm{H}^{+}\end{array}$

The current efficiency is a vital parameter for the EC process as a result of its affects on the time period of the probes. Electrochemically, according to Faraday's law, whenever one Faraday of charge passes through the circuit, about $9.0 \mathrm{~g}$ of aluminum is dissolved at anode. On the other hand, the electrochemical side-reactions, the real anode utilization might be diminished or prolonged from this hypothetical respect depending on the wastewater qualities and operational conditions [31].

$\mathrm{P}\left({ }_{\text {Watt }}\right)=\mathrm{VIt}$

$\%$ Current Efficiency $=\mathrm{M}_{\mathrm{O}} / \mathrm{M}_{\mathrm{T}} \times 100$

\subsection{Influences of Current on Removal Potency}

The electric current not only influences on the coagulants formation, additionally, the fizz formation rate, their size and also the flocs chain. To analyze the electric current effect, a series of experiments were performed with 0.2$1.41 \mathrm{~A}$ at neutral $\mathrm{pH}$ and $4.0 \mathrm{~g}$ optimum value of $\mathrm{NaCl}$. The percent removal was improved from $20-60 \%$. The results are showing that the higher current means large population of electrons are available to the electrochemical cell that enhanced the removal potency of dye. However, high generation of current could increase undesirable side-responses like scrounging loss reactions leading to the depletion of hypochlorite concentration [32]. At high current the quantity of metal hydroxide coagulants formation is enhanced. Hence, the rate of removal of pollutants from wastewater is also increased [33]. 


\subsection{Impacts of Quantity of Electrolyte on Removal Efficiency}

Conductivity of the wastewater plays an important role to decrease cell's voltage and the energy utilization. It was found by researchers [33-34] that the rate of dye removal enhanced by using $\mathrm{NaCl}$, because of the formation of hypochlorite. The anodic oxidation of chloride ions resulted the chlorine evolutions as shown in Equations (16-17). In water, chlorine rapidly disproportionates and yields hypochloric acid $\left(\mathrm{HClO}_{4}\right)$ and hypochlorite ion $\left(\mathrm{OCl}^{-}\right)$, which can rapidly oxidize organic composites by electrochemical degradation as a result of indirect oxidation [35]. To study the effect of $\mathrm{NaCl}$ concentration on the removal proficiency of the RR120, its amount was varied from 2.0-10.0g. Fig. 10 illustrates that the removal efficiency is depending on the supporting electrolyte dose. The concentration of chloride plays an imperative role in the electro-oxidation process [34-35]. Moreover, it also decreases the passivity of the electrode surface due to its catalytic action [36]. The formation of $\mathrm{H}_{2} \mathrm{O}_{2}$, which is result of the cathodic reaction of atomic oxygen and has been proposed as a supportive compound for dye removal at current of high densities [38].

TABLE 5. EVALUATION OF CURRENT EFFICIENCY AND ENERGY COST

\begin{tabular}{|c|c|c|c|c|c|c|c|}
\hline $\begin{array}{c}\text { Concentration of } \\
\text { RR120 } \\
(\mathrm{mg} / \mathrm{L})\end{array}$ & $\begin{array}{c}\text { Current } \\
\text { Efficiency } \\
(\%)\end{array}$ & $\begin{array}{c}\text { Energy } \\
\text { Consumption } \\
\left(\mathrm{KWH} / \mathrm{dm}^{3}\right)\end{array}$ & $\begin{array}{c}\text { Cost of Energy } \\
(\mathrm{US} \$ \mathrm{KWH})\end{array}$ & $\begin{array}{c}\text { Cost of } \\
\text { Electrode } \\
(\mathrm{US} \$ / \mathrm{Kg})\end{array}$ & $\begin{array}{c}\text { Removal } \\
(\%)\end{array}$ & $\begin{array}{c}\text { After } \\
\text { Current } \\
(\mathrm{A})\end{array}$ & $\begin{array}{c}\text { Amount of } \\
\text { NaCl } \\
(\mathrm{g})\end{array}$ \\
\hline 100 & 154 & 0.0047 & $6 \times 10-5$ & $1.18 \times 10-3$ & 100 & $\begin{array}{c}\text { Treatment } \\
\text { Color of } \\
\text { Water }\end{array}$ \\
\hline 200 & 112 & 0.0065 & $8 \times 10-5$ & $1.71 \times 10-3$ & 100 & 0.6 & 4 \\
\hline 300 & 108 & 0.0095 & $12 \times 10-5$ & $2.42 \times 10-3$ & 100 & 0.6 & 4 \\
\hline 400 & 116 & 0.01 & $13 \times 10-5$ & $2.73 \times 10-3$ & 100 & 0.6 & 4 \\
\hline 500 & 123 & 0.011 & $14 \times 10-5$ & $2.44 \times 10-3$ & 100 & 0.6 & Light Yellow \\
\hline
\end{tabular}

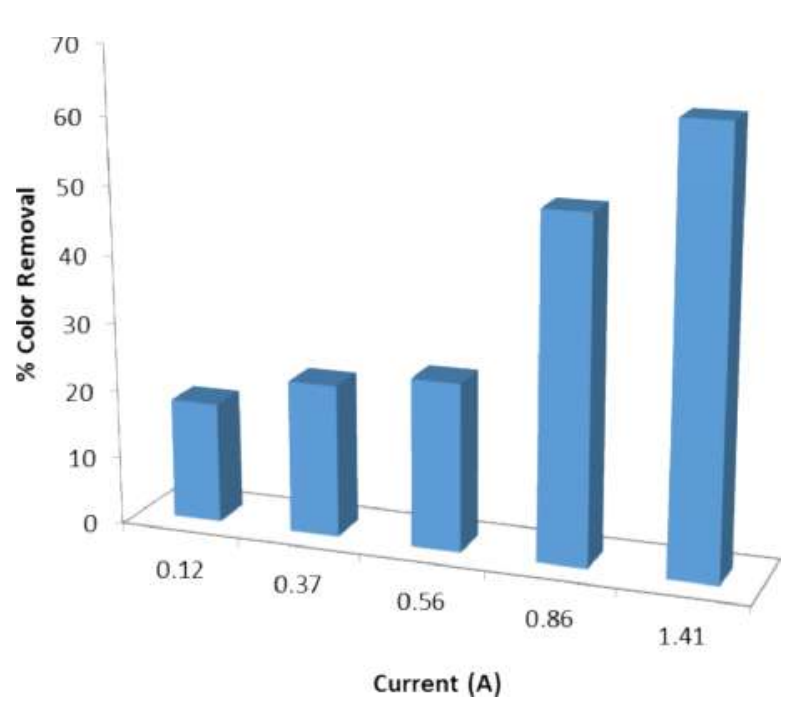

FIG. 9. EFFECT OF CURRENT ON THE \% REMOVAL OF RR120 DYE $(C O=120 \mathrm{mg} / \mathrm{L}$, SONICATION TIME $=120 \mathrm{~min}$, $V O L U M E=1000 \mathrm{~mL}$ ).

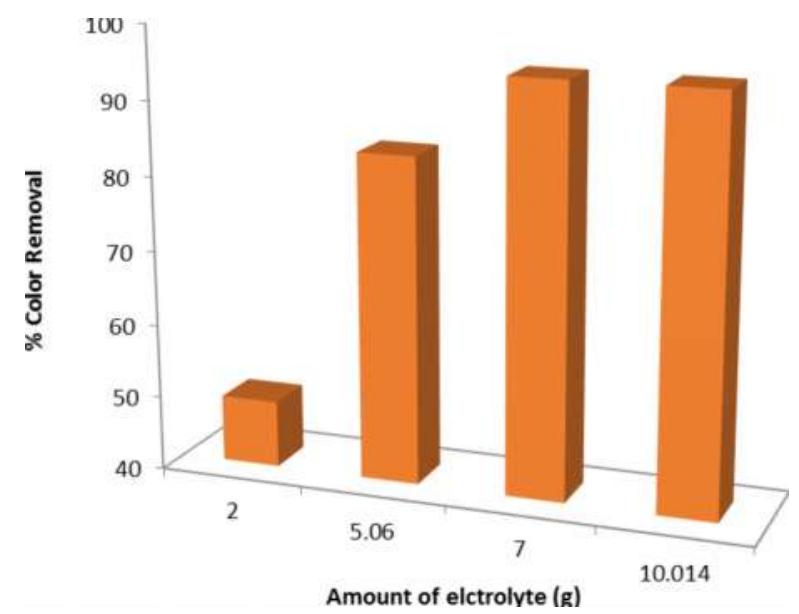

FIG. 10. EFFECT OF AMOUNT OF NACL ON REMOVAL OF DYE RR120 (120 mg/L), SONICATION TIME = $120 \mathrm{~min}$, VOLUME $=1000 \mathrm{~mL}$ )

Mehran University Research Journal of Engineering \& Technology, Volume 38, No. 2, April, 2019 [p-ISSN: 0254-7821, e-ISSN: 2413-7219] 


\subsection{Temperature Effect on EC Process}

The influence of temperature on the sonoelectrocoagulation process was studied at $30^{-4} 45^{\circ} \mathrm{C} \pm$ $0.1^{\circ} \mathrm{C}$. The results are shown in Fig. 11(a-b), they show that at higher temperatures the removal efficiency is enhanced. Therefore, a linear dependency is observed on the flocculation of dye, since the dye removal follows temperature variations linearly. On the other hand, the dye molecules are discharged into effluent at elevated temperature and reduces the dye removal proficiency. One of the important feature is to be considered that as the temperature increases the rate of diffusion is affected.

The amount of $\mathrm{Al}(\mathrm{OH})_{3}\left(\mathrm{D}_{\mathrm{F}}\right)$ is determined by the Faraday's law of electrolysis as represented in Equation (21):

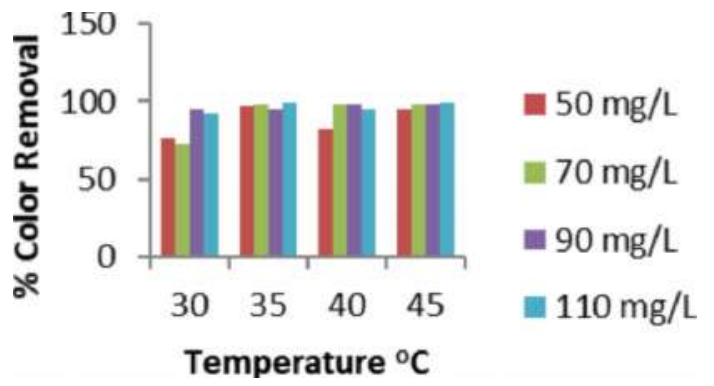

FIG. 11(a). EFFECT OF TEMPERATURE ON \% REMOVAL OF DIFFERENT DYE CONCENTRATIONS $(\mathrm{mg} / \mathrm{L})$

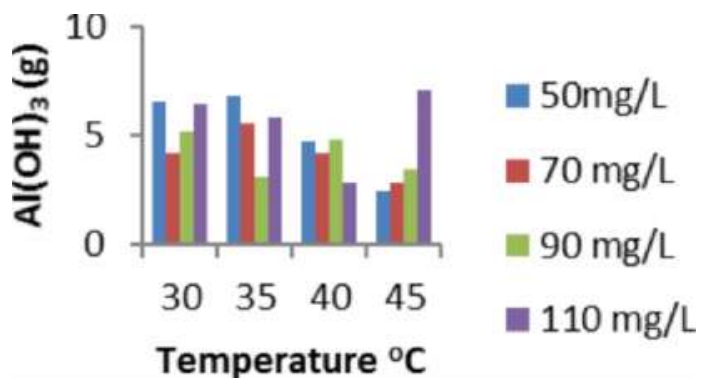

FIG. 11(b). TEMPERATURE EFFECT ON THE AMOUNT OF $A L(O H)_{3}$ FORMATION AT VARIABLE CONCENTRATIONS $(m g / L)$
$\mathrm{D}_{\mathrm{F}}=\mathrm{It} \mathrm{M} / \mathrm{Z}$

where the symbol of the electric current is I, the unit of current is Ampere (A), $\mathrm{t}$ is the time (s), $\mathrm{M}$ is the atomic mass, $Z$ is the electron involved, and $F$ is the Faraday constant (96485.3 C/mol).

\section{CONCLUSION}

The present work highlighted the remediation of textile industrial pollution. The sono-electrocoagulation process was efficaciously optimized and obtained 100\% dye removal from simulated effluent at optimum levels of factors. The optimum values were determined by RSM. The CCD model was significant which was verified from high $\mathrm{R}^{2}(0.8226)$ value by ANOVA. The effluent of the sono-electrocoagulation treatment possesed properties like palatable, flawless, monochrome and unscented that could be reuse except drinking. After the analysis of data. It was found that the ultrasound irradiation improved the performance of the process in the presence of activated carbon. In the experimental reactor, Aluminium and Carbon electrodes were used successfully for the treatment of simulated discharge. Furthermore, Main and Full interaction plots were also indicated that the corresponding parameters extensively affect on response of the s sono-electrocoagulation process. In the future study, the sono-electrocoagulation process will be applied for the treatment of effluent of SITE Industrial Zone, Karachi, Pakistan.

\section{ACKNOWLEDGMENT}

The work was done in collaboration with Department of Chemistry, University of Karachi, Karachi, Pakistan. 


\section{REFERENCES}

He, C.C., Hu, C.Y., and Lo, S.L., "Evaluation of SonoElectrocoagulation for the Removal of Reactive Blue 19|Passive Film Removed by Ultrasound", Separation and Purification Technology, Volume 165, pp. 107-113, Taiwan, 2016

Kobya, M., Can, O.T., and Bayramoglu, M., "Treatment of Textile Wastewaters by Electrocoagulation Using Iron and Aluminum Electrodes", Journal of Hazardous Materials, Volume 100, No.1, pp. 163-178, Turkey, 2003.

[3]

Lakshmi, P.M., and Sivashanmugam, P., "Treatment of Oil Tanning Effluent by Electrocoagulation: Influence of Ultrasound and a Hybrid Electrode on COD Removal", Separation and Purification Technology, Volume 116, pp. 378-384, India, 2013.

[4]

Raschitor, A., Fernandez, C.M., Cretescu, I., Rodrigo, M.A., and Cañizares, P., "Sono-Electrocoagulation of Wastewater Polluted with Rhodamine 6G", Separation and Purification Technology, Volume 135, pp.110-116, Spain, 2014.

Hamdan, S.S., and El-Naas, M.H., "An Electrocoagulation Column (ECC) for Groundwater Purification”, Journal of Water Process Engineering, Volume 4, pp. 25-30, United Arab Emirates, 2014.

[6] Dahlem, O., Reisse, J., and Halloin, V., “ The Radially Vibrating Horn: A Scaling-Up Possibility for Sonochemical Reactions", Chemical Engineering Science, Volume 54, No. 13-14, pp. 2829-2838, Belgium, 1999.

Lacasa, E., Canizares, P., and Rodrigo, M.A., "Production of Coagulant Reagents for Electro-Coagulation Processes at Low Current Densities", Desalination and Water Treatment, Volume 45, No. 1-3, pp. 256-262, Spain, 2012.

Mollah, M.Y.A., Schennach, R., Parga, J.R., and Cocke, D.L., "Electrocoagulation (EC)-Science and Applications", Journal of Hazardous Materials, Volume 84, No. 1, pp. 29-41, Bangladesh, 2001.
[9] Stack, L.J., Carney, P.A., Malone, H.B., and Wessels, T.K., " Factors Influencing the Ultrasonic Separation of Oil-in-Water Emulsions", Ultrasonics Sonochemistry, Volume 1, No. 3, pp. 153-160, USA, 2005.

[10] Can, O.T., Kobya, M., Demirbas, E., and Bayramoglu, M., "Treatment of the Textile Wastewater by Combined Electrocoagulation”, Chemosphere, Volume 62, No. 2, pp. 181-187, Turkey, 2006.

[11] Yuksel, E., Gurbulak, E., and Eyvaz, M., “ Decolorization of a Reactive Dye Solution and Treatment of a Textile Wastewater by Electrocoagulation and Chemical Coagulation: Techno Economic Comparison", Environmental Progress \& Sustainable Energy, Volume 31, No. 4, pp. 524-535, Turkey, 2012.

[12] Sivakumar, M., and Pandit, A.B., "Wastewater Treatment: a Novel Energy Efficient Hydrodynamic Cavitational Technique", Ultrasonics Sonochemistry, Volume 9, No. 3, pp. 123-131, India, 2002.

[13] Un, U.T., Kandemir, A., Erginel, N., and Ocal, S.E., "Continuous Electrocoagulation of Cheese Whey Wastewater: An Application of Response Surface Methodology”, Journal of Environmental Management, Volume 146, pp. 245-250, Turkey, 2014.

[14] Jiang, J.Q., Graham, N., André, C., Kelsall, G.H., and Brandon, N., "Laboratory Study of Electro-CoagulationFlotation for Water Treatment", Water Research, Volume 36, No. 16, pp. 4064-4078, UK, 2002.

[15] Chen, X., Chen, G., and Yue, P.L., "Separation of Pollutants from Restaurant Wastewater by Electrocoagulation", Separation and Purification Technology, Volume 19, No. 1, pp. 65-76, China, 2000.

[16] Kushwaha, J.P., Srivastava, V.C., and Mall, I.D., "Organics Removal from Dairy Wastewater by Electrochemical Treatment and Residue Disposal", Separation and Purification Technology, Volume 76, No. 2, pp. 198-205, India, 2010. 
[17] Alinsafi, A., Khemis, M., Pons, M.N., Leclerc, J.P., Yaacoubi, A., Benhammou, A., and Nejmeddine, A., "Electro-Coagulation of Reactive Textile Dyes and Textile Wastewater", Chemical Engineering and Processing: Process Intensification, Volume 44, No. 4, pp. 461-470, France, 2005

Dasgupta, J., Singh, M., Sikder, J., Padarthi, V., Chakraborty, S., and Curcio, S., "Response SurfaceOptimized Removal of Reactive Red 120 Dye from Its Aqueous Solutions Using Polyethyleneimine Enhanced Ultrafiltration", Ecotoxicology and Environmental Safety, Volume 121, pp. 271-278, India, 2015.

Paul, J., Rawat, K.P., Sarma, K.S.S., and Sabharwal, S., "Decoloration and Degradation of Reactive Red-120 Dye by Electron Beam Irradiation in Aqueous Solution", Applied Radiation and Isotopes, Volume 69, No. 7, pp. 982-987, India, 2011.

[20] Mahamuni, N.N., and Adewuyi, Y.G., "Advanced Oxidation Processes (AOPs) Involving Ultrasound for Waste Water Treatment: A Review with Emphasis on Cost Estimation", Ultrasonics Sonochemistry, Volume 17, No. 6, pp. 990-1003, USA, 2010.

[21] Saharan, V.K., Badve, M.P., and Pandit, A.B., "Degradation of Reactive Red 120 Dye Using Hydrodynamic Cavitation", Chemical Engineering Journal, Volume 178, pp. 100-107, India, 2011.

Goel, M., Hongqiang, H., Mujumdar, A.S., and Ray, M.B., "Sonochemical Decomposition of Volatile and NonVolatile Organic Compounds: A Comparative Study", Water Research, Volume 38, No. 19, pp. 4247-4261, Singapore, 2004.

[23] Borbély, G., and Nagy, E., “ Removal of Zinc and Nickel Ions by Complexation-Membrane Filtration Process from Industrial Wastewater", Desalination, Volume 240, No. 1-3, pp. 218-226, Hungary, 2009.

[24] Chen, X., Chen, G., and Yue, P.L., "Anodic Oxidation of Dyes at Novel Ti/B-Diamond Electrodes", Chemical Engineering Science, Volume 58, No. 3, pp. 995-1001, China, 2003.
[25] Raju, G.B., Karuppiah, M.T., Latha, S.S., Parvathy, S., and Prabhakar, S., "Treatment of Wastewater from Synthetic Textile Industry by ElectrocoagulationElectrooxidation", Chemical Engineering Journal, Volume 144, No. 1, pp. 51-58, India, 2008

Oller, I., Malato, S., and Sánchez-Pérez, J., "Combination of Advanced Oxidation Processes and Biological Treatments for Wastewater Decontamination: A Review", Science of the Total Environment, Volume 409 No. 20, pp. 4141-4166, Spain, 2011.

[27] Brillas, E., and Martínez-Huitle, C.A., "Decontamination of Wastewaters Containing Synthetic Organic Dyes by Electrochemical Methods: An Updated Review", Applied Catalysis-B: Environmental, Volume 166, pp. 603-643, Spain, 2015.

[28] Aber, S., Amani-Ghadim, A.R., and Mirzajani, V., "Removal of $\mathrm{Cr}(\mathrm{VI})$ from Polluted Solutions by Electrocoagulation: Modeling of Experimental Results Using Artificial Neural Network”, Journal of Hazardous Materials, Volume 171, No. 1, pp. 484-490, Iran, 2009.

[29] Llanos, J., Cotillas, S., Cañizares, P., and Rodrigo, M.A., "Conductive Diamond Sono-Electrochemical Disinfection (CDSED) for Municipal Wastewater Reclamation”, Ultrasonics Sonochemistry, Volume 22, pp. 493-498, Spain, 2015.

[30] Yildiz, Y.a., Koparal, A.S., Ýrdemez, P., and Keskinler, B., "Electrocoagulation of Synthetically Prepared Waters Containing High Concentration of NOM Using Iron Cast Electrodes", Journal of Hazardous Materials, Volume 139, No. 2, pp. 373-380, Turkey, 2007.

[31] Golder, A.K., Samanta, A.N., and Ray, S., "Removal of Trivalent Chromium by Electrocoagulation", Separation and Purification Technology, Volume 53, No. 1 , pp. 33-41, India, 2007.

[32] Katal, R., and Pahlavanzadeh, H.. "Influence of Different Combinations of Aluminum and Iron Electrode on Electrocoagulation efficiency: Application to the Treatment of Paper Mill Wastewater", Desalination, Volume 265, No. 1, pp. 199-205, Iran, 2011. 
[33] Mollah, M.Y.A., Schennach, R., Parga, J.R., and Cocke, D.L., "Electrocoagulation (EC) - Science and Applications", Journal of Hazardous Materials, Volume 84, No.1, pp. 29-41, USA, 2001.

[34] El-Ashtoukhy, E.Z., and Amin, N.K., "Removal of Acid Green Dye 50 from Wastewater by Anodic Oxidation and Electrocoagulation: A Comparative Study", Journal of Hazardous Materials, Volume 179, No. 1, pp. 113-11, Egypt, 2010.

[35] Picard, T., Cathalifaud-Feuillade, G., Mazet, M., and Vandensteendam, C., "Cathodic Dissolution in the Electrocoagulation Process Using Aluminium Electrodes", Journal of Environmental Monitoring, Volume 2, No. 1, pp. 77-80, France, 2000.
[36] Canizares, P., Carmona, M., Lobato, J., Martinez, F., and Rodrigo, M.A., "Electrodissolution of aluminum Electrodes in Electrocoagulation Processes", Industrial \& Engineering Chemistry Research, Volume 44, No. 12, pp. 4178-4185, Spain, 2005.

[37] Chen, X., Chen, G., and Yue, P.L., "Separation of Pollutants from Restaurant Wastewater by Electrocoagulation", Separation and Purification Technology, Volume 19, No. 1, pp. 65-7 6, China, 2000.

[38] Calvete, T., Lima, E.C., Cardoso, N.F., Vaghetti, J.C., Dias, S.L., and Pavan, F.A., "Application of Carbon Adsorbents Prepared from Brazilian-Pine Fruit Shell for the Removal of Reactive Orange 16 from Aqueous Solution: Kinetic, Equilibrium, and Thermodynamic Studies", Journal of Environmental Management, Volume 91, No. 8, pp. 1695-1706, Brazil, 2010. 